\title{
NOD2 and reproduction-associated NOD-like receptors have been lost during the evolution of pangolins
}

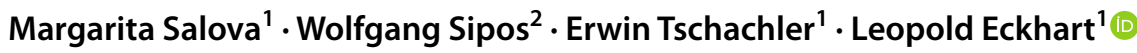

Received: 18 September 2021 / Accepted: 20 October 2021 / Published online: 1 November 2021

(c) The Author(s) 2021

\begin{abstract}
NOD-like receptors (NLRs) are sensors of pathogen-associated molecular patterns with critical roles in the control of immune responses and programmed cell death. Recent studies have revealed inter-species differences in mammalian innate immune genes and a particular degeneration of nucleic acid sensing pathways in pangolins, which are currently investigated as potential hosts for zoonotic pathogens. Here, we used comparative genomics to determine which NLR genes are conserved or lost in pangolins and related mammals. We show that NOD2, which is implicated in sensing bacterial muramyl dipeptide and viral RNA, is a pseudogene in pangolins, but not in any other mammalian species investigated. NLRC4 and NAIP are absent in pangolins and canine carnivorans, suggesting convergent loss of cytoplasmic sensing of bacterial flagellin in these taxa. Among NLR family pyrin domain containing proteins (NLRPs), skin barrier-related NLRP10 has been lost in pangolins after the evolutionary divergence from Carnivora. Strikingly, pangolins lack all NLRPs associated with reproduction (germ cells and embryonic development) in other mammals, i.e., NLRP2, 4, 5, 7, 8, 9,11,13, and 14. Taken together, our study shows a massive degeneration of NLR genes in pangolins and suggests that these endangered mammals may have unique adaptations of innate immunity and reproductive cell biology.
\end{abstract}

Keywords NOD2 $\cdot$ NLRP $\cdot$ Innate immunity $\cdot$ Inflammation $\cdot$ Pangolin $\cdot$ Zoonosis $\cdot$ Gene loss

\section{Introduction}

Nucleotide-binding oligomerization domain (NOD)-like receptors (NLRs) are a family of proteins involved in the defense against pathogens and in reproduction (Fig. 1). NLRs are characterized by the presence of a NOD, also known as NACHT domain, which is followed by leucinerich repeats (LRRs). The NOD/NACHT domain mediates self-oligomerization upon binding of a ligand to LRRs. In addition, NLRs contain other domains such as 1 or 2 caspase recruitment domains (CARDs) or a pyrin domain (PYD), which mediate interactions with other proteins to control the initiation of inflammation, programmed cell death and other processes (Inohara et al. 2005; Fritz et al. 2006; Ting et al.

Leopold Eckhart

leopold.eckhart@meduniwien.ac.at

1 Department of Dermatology, Medical University of Vienna, Vienna, Austria

2 Clinical Department for Farm Animals and Herd Management, University of Veterinary Medicine Vienna, Vienna, Austria
2008; Zhang et al. 2010; Elinav et al. 2011; Zhong et al. 2013; Geddes et al. 2009; Heim et al. 2019; Kienes et al. 2021; Danis et al. 2021). Regulators of immune defense have played critical roles in the evolution of host-pathogen interactions, leading to the diversification of defense strategies at the molecular level (Danilova 2006; Eckhart et al. 2005; Zhang et al. 2010; Chakraborty and Ghosh 2020).

The main subfamilies of NLRs are the NLR family CARD domain containing (NLRC) proteins and the NLR family pyrin domain containing (NLRP) proteins. Humans have 5 NLRCs (NOD1, NOD2, NLRC3-5) and 14 NLRPs (NLRP1-14). The primordial function of NLRs is the detection of pathogen-associated molecular patterns (PAMPs) and damage-associated molecular patterns (DAMPs), which include bacterial cell wall components, such as fragments of peptidoglycan that are sensed by NOD1 and NOD2 (Philpott et al. 2014; Wolf and Underhill 2018), viral RNAs which are sensed by NOD2 and NLRP6 (Sabbah et al. 2009; Wang 2015; Liu and Gack 2020), and others (Kuss-Duerkop et al. 2020; Pei et al. 2021). NLRs were originally identified as activators of inflammation and immune responses, but later research has demonstrated anti-inflammatory roles of 


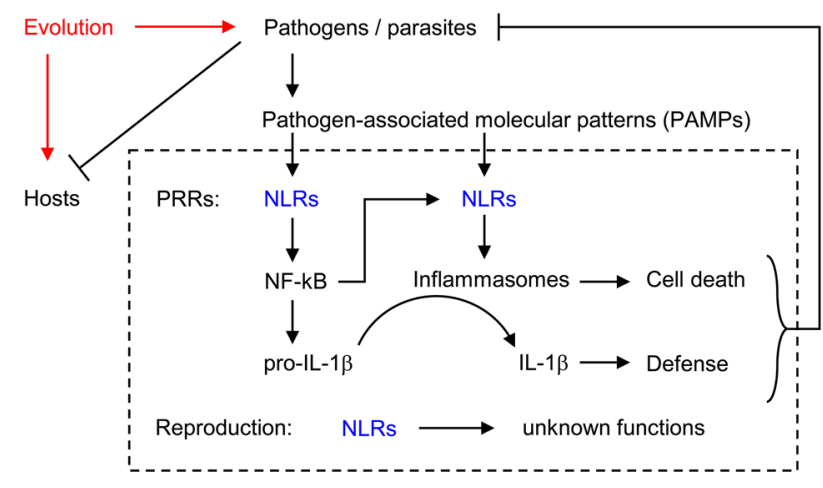

Fig. 1 Roles of NOD-like receptors (NLRs). NLRs are involved in the activation of NF-kB-dependent gene expression and inflammasomedependent cell death and immune responses. Besides their role in the defense against pathogens, NLRs have also unknown functions in the reproductive system. Evolution has shaped host-pathogen interactions and control mechanisms of reproduction in mammals

several NLRs, such as NLRC3 (Li et al. 2019) and NLRP12 (Williams 2005; Chen et al. 2019).

Besides functions in innate immunity, NLRPs are implicated in germ cell biology and early embryonic development. There are nine human NLRPs that appear to have functions related to reproduction: $N L R P 2, N L R P 4, N L R P 5, N L R P 7$, NLRP8, NLRP9, NLRP11, NLRP13, and NLRP14 (Tian et al. 2009; Zhang et al. 2008; Abe 2017; Amoushahi et al. 2019; Yin et al. 2020). These NLRP genes, which are phylogenetically distinct from other NLRPs (Tian et al. 2009), are expressed in germ cells and pre-implantation embryos (Zhang et al. 2008). Gene knockout studies showed that $N L R P 2$ controls age-associated maternal fertility (Kuchmiy et al. 2016), NLRP5 is required for early embryonic development (Tong et al. 2000), and NRLP14 is essential for differentiation of spermatogonial stem cells in mice (Yin et al. 2020). The mechanisms of action of reproduction-associated NLRPs are elusive.

Pangolins (order: Pholidota) are nocturnal mammals that feed on ants and termites. Phylogenetically, they are most closely related to carnivorans (order: Carnivora), a clade comprised of cat-like (Feliformia) and dog-like (Caniformia) mammals with the latter including canines, bears, procyonids (raccoons and relatives), mustelids (weasels and relatives), skunks (mephitids), red pandas (ailurids), and pinnipeds. The body of pangolins is covered by keratinous scales which serve as a protective armor (Choo et al. 2016; $\mathrm{Li}$ et al. 2020). Few comparative studies of the mammalian immune defense have included pangolins, but the interest in pangolins has increased recently due their possible role as intermediate hosts for the pandemic severe acute respiratory syndrome coronavirus 2 (SARS-CoV-2), a betacoronavirus with a single-stranded RNA genome (Lam et al. 2020; Xiao et al. 2020; Zhang et al. 2020; Andersen et al. 2020).
Recently, we have reported that interferon-induced with helicase C domain 1 (IFIH1)/MDA5, Z-DNA-binding protein (ZBP1), cyclic GMP-AMP synthase (cGAS), and stimulator of interferon genes (STING), which initiate innate immune responses to intracellular nucleic acids, have been lost during the evolution of pangolins (Fischer et al. 2020a, b). Likewise, toll-like receptor (TLR) 5 , an endosomal receptor of bacterial flagellin, is absent in pangolins (Sharma et al. 2020).

Here we investigated whether NLR genes are conserved in pangolins and found that NOD2 and several other NLRs have underdone pseudogenization or were entirely lost, indicating that immune responses to specific pathogens and NLR-dependent processes in the reproduction system are altered in pangolins.

\section{Materials and methods}

Genes were identified in the genome sequences of the Malayan pangolin (Manis javanica), Assembly: ManJav1.0 (GCA_001685135.1), submitted by the International Pangolin Research Consortium (Choo et al. 2016); Chinese pangolin (M. pentadactyla), Assembly: M_pentadactyla-1.1.1 (GCA_000738955.1), submitted by Washington University; and tree pangolin (Phataginus tricuspis, previously named Manis tricuspis), Assembly: ManTri_v1_BIUU (GCA_004765945.1), submitted by Broad Institute. At the time of this study (July 2021), GenBank gene annotations were available for M. javanica (NCBI Manis javanica Annotation Release 100) and M. pentadactyla (NCBI Manis pentadactyla Annotation Release 100) but not for the other species of pangolins. Other nucleotide sequences were downloaded from GenBank, and accession numbers are indicated in the text.

Sequence similarities were identified with the Basic Local Alignment Search Tool (BLAST) (Altschul et al. 1990). Nucleotide sequences were translated into amino acid sequences using the Translate tool at the Expasy website of the Swiss Institute of Bioinformatics (https://web.expasy. org/translate/). Sequences were aligned with MUSCLE (https://www.ebi.ac.uk/Tools/msa/muscle/) and Multalin (http://multalin.toulouse.inra.fr/multalin/). Phylogenetic relationships and divergence times were obtained from the Timetree website (www.timetree.org) (Hedges et al. 2015).

\section{Results}

\section{NOD2 is inactivated by gene mutations in pangolins}

We investigated foreign nucleic acid response genes in the Malayan pangolin, a species that is considered a potential 
intermediate host of the SARS-CoV-2 (Lam et al. 2020; Xiao et al. 2020; Zhang et al. 2020; Niu et al. 2021). Comparative analysis of NOD2, which had been reported to be involved in sensing single-stranded RNA (Sabbah et al. 2009), showed that a NOD2 gene locus is present in pangolins, dog, cattle, and human (Fig. 2a). However, frame-shift and premature stop mutations were detected in exons 1, 3, 4, 5, and 8 of $M$. javanica NOD2 (Fig. 2b). Analysis of genome sequences of two other pangolin species, the Chinese and the tree pangolin, revealed that inactivating mutations were also present in those species, whereby a frame-shift mutation leading to a premature stop of the reading frame in exon 1 was identified in all three species of pangolins investigated (Fig. 2c). By contrast, NOD2 is intact in all other mammalian species investigated (Suppl. Fig. S1). These data suggest that NOD2 has been inactivated by a gene mutation in the last common ancestor of pangolins (Fig. 2d).

\section{NLRC4 and NAIP are inactivated by gene mutations in pangolins}

Next we investigated whether the inactivation of NOD2 is unique among NLR family genes in pangolins. We analyzed the loci of NLR genes and flanking genes in human, cattle, dog, and the Malayan pangolin. The nucleotide sequences of all NLR gene homologs were screened for the presence of mutations that would disrupt the coding sequences. NOD1, CIITA, NLRX1, NLRC3, and NLRC5, which is comprised of 47 exons in the pangolin and encodes the longest of all NLR proteins with 1859 amino acids, are free from inactivating
Fig. 2 NOD2 is a pseudogene in pangolins. a Gene locus of NOD2 in the Malayan pangolin, dog, cattle, and human. Genes are represented by arrows pointing into the direction of transcription. The mutated NOD2 gene is shown as a broken arrow. b Inactivating mutations in multiple exons of pangolin NOD2. Positions of frame-shift and premature stop mutations are indicated by vertical arrows. Exons of NOD2 of pangolin, dog, cattle and human are shown as boxes. c Nucleotide sequence alignment of a segment of exon 1 that contains a conserved frame-shift mutation (red shading) leading to a premature stop codon (grey shading) in three species of pangolins. Nucleotides identical in all species are shown with blue fonts. $\mathbf{d}$ The absence (-) or presence $(+)$ of intact NOD2 in 6 species was used to map the NOD2 gene loss (flash symbol) on a simplified phylogenetic tree of mammals. Species: Malayan pangolin (Manis javanica), Chinese pangolin (Manis pentadactyla), tree pangolin (Phataginus tricuspis), dog (Canis lupus familiaris), cattle (Bos taurus), and human (Homo sapiens) a

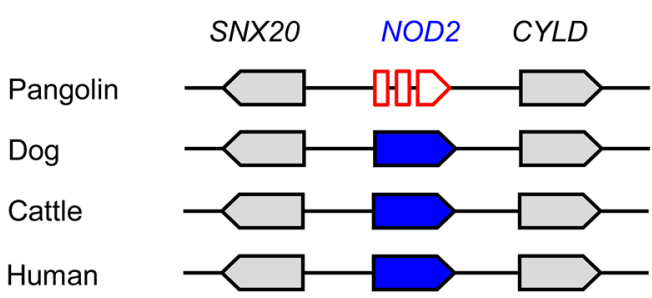

b

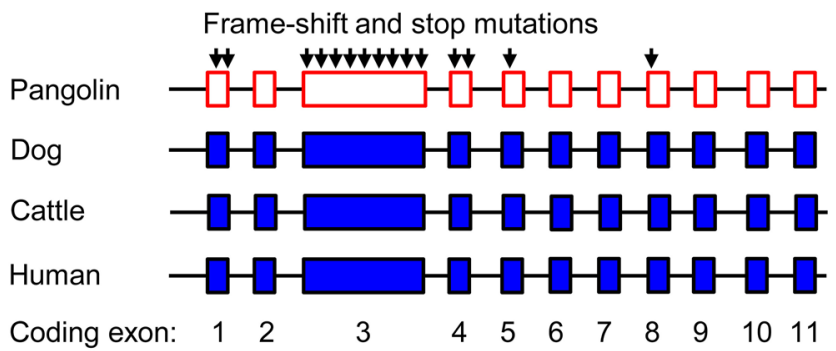

C

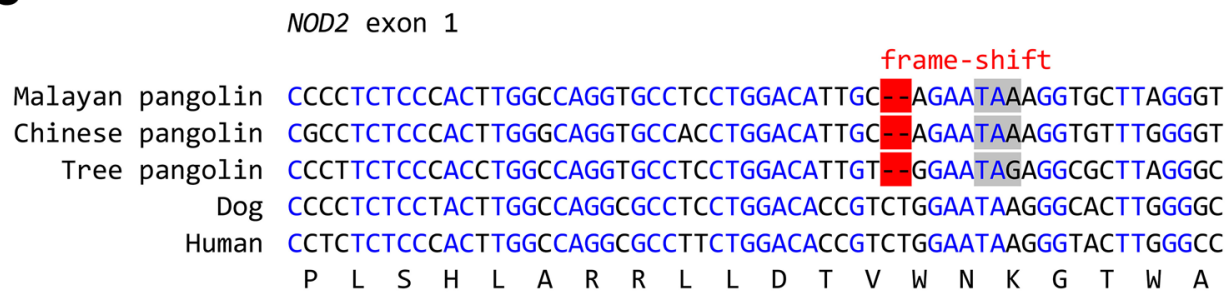

d

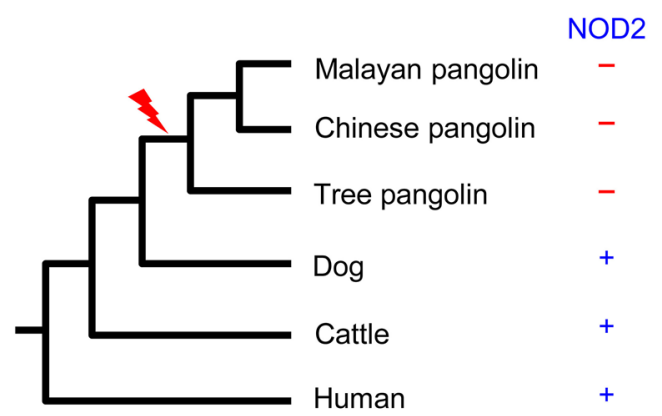


mutations in the four aforementioned species. By contrast, $N L R C 4$ was entirely absent from the genomes of pangolins (M. javanica, M. pentadactyla, Phataginus tricuspis) although both genes flanking NLRC4 in the human genome are conserved (Fig. 3a). In line with the results of a previous study (Eckhart et al. 2009), NLRC4 contains inactivating mutations in the dog. NLRC4 is also a pseudogene in the ermine (Mustela erminea) but not in the cat. These data indicated that NLRC4 was inactivated in the last common ancestor of pangolin and, by parallel evolution, in the last common ancestor of Caniformia ("dog-like" carnivorans, including dogs, mustelids, bears, pinnipeds, and others) (Fig. 3a).

Strikingly, the second receptor of intracellular flagellin, i.e., NLR family apoptosis inhibitory protein (NAIP), is also absent from pangolins and caniforms (Fig. 3b). We conclude that parallel evolution has led to the loss of both NLR proteins involved in intracellular flagellin detection in pangolins and caniforms.

a
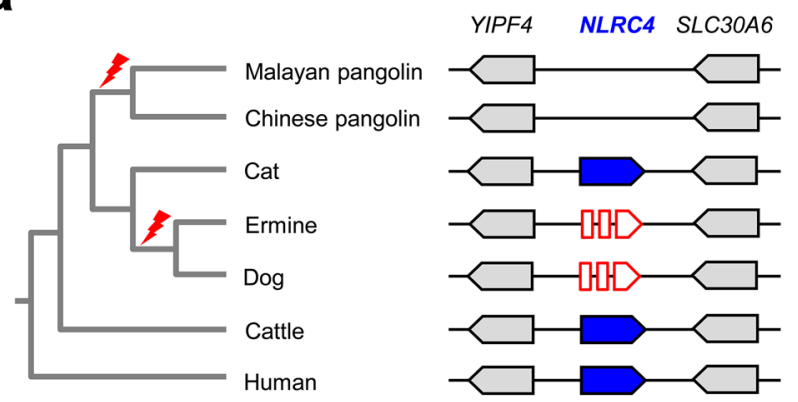

b

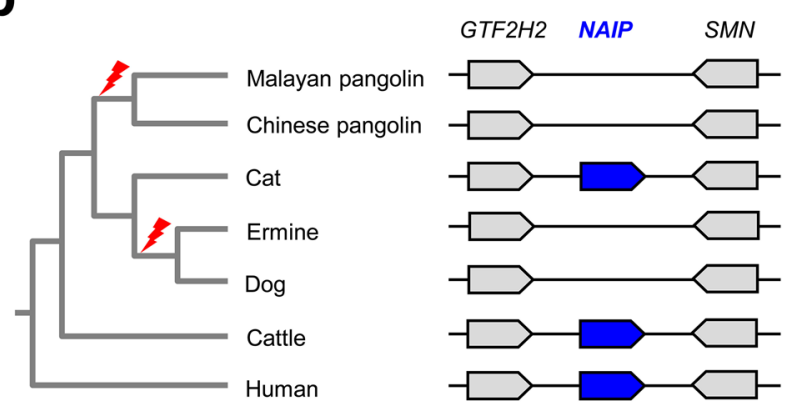

Fig. 3 Absence of NLRC4 and NAIP in pangolins. a Gene locus of $N L R C 4$. Genes are represented by arrows pointing into the direction of transcription. Intact NLRC4 genes are shown as blue arrows. Red broken arrows indicate inactivating mutations of $N L R C 4$ in caniformia, represented by dog and ermine. NLRC4 is absent in pangolins. Loss of NAIP was mapped (red flash symbols) onto a simplified phylogenetic tree of mammals. b Gene locus of NAIP. Genes are represented by arrows pointing into the direction of transcription. Intact NAIP genes are shown as blue arrows. NAIP is absent in pangolins, dog, and ermine. Loss of NAIP was mapped (red flash symbols) onto a simplified phylogenetic tree of mammals. Species: Malayan pangolin (Manis javanica), Chinese pangolin (Manis pentadactyla), cat (Felis catus), ermine (Mustela erminea), dog (Canis lupus familiaris), cattle (Bos taurus), and human (Homo sapiens)
The majority of NLRP genes have been inactivated in pangolins

NLRP genes represent the largest group of NLR genes with 14 members in the human genome. Comparative genomics showed that NRLP1 (Fig. 4a), NLRP3, NLRP6, and $N L R P 12$ are conserved in pangolins, whereas NLRP2 and 7, which are neighbors in the human genome (Fig. 4b); NLRP4, 5, 8, 9, 11, and 13 , which are clustered in the human genome (Fig. 4c); and NLRP10 (Fig. 4d) are absent from the genomes of pangolins. Absence was confirmed by BLAST searches against entire genome sequences and against the genome region between orthologs of genes that flank the aforementioned NLRP genes in other mammalian species (Fig. 4b-d). An ortholog of NLRP14 is present in pangolins, but its coding sequence is disrupted by inactivating mutations (Fig. 4e; Suppl. Fig. S2).

In total, there are only 8 intact NLR genes in the Malayan pangolin, as compared to 20 in human and 15 in both cattle and dog (Table 1). Remarkably, nine NLRPs that are predominantly or exclusively expressed in germ cells and early stages of embryonic development, i.e., NLRP2, NLRP4, NLRP5, NLRP7, NLRP8, NLRP9, NLRP11, NLRP13, and $N L R P 14$, lack orthologs in pangolins (Table 1).

a

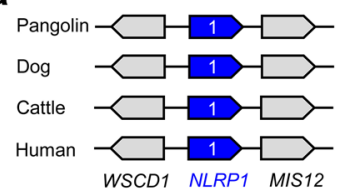

b

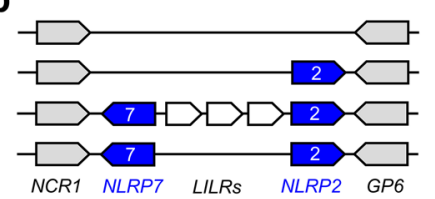

C

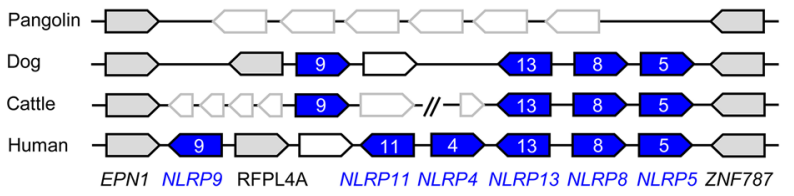

d

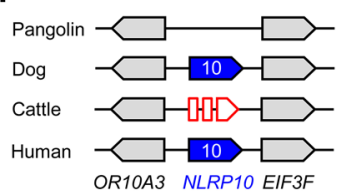

e

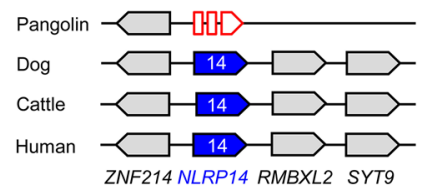

Fig. 4 Absence of multiple $N L R P$ genes in pangolins. Gene loci of $N L R P 1$ a, NLRP2 and NLRP7 b, NLRP4, NLRP5, NLRP8, NLRP9, $N L R P 11$, and NLRP13 c, NLRP10 d, and NLRP14 e of Malayan pangolin, dog, cattle, and human are schematically depicted. Intact NLRP genes are shown as blue arrows with white numbers indicating the number of the NLRP gene. Red broken arrows indicate NLRP genes that are inactivated by mutations. Grey arrows indicate evolutionarily conserved genes flanking NLRP genes. White arrows represent genes that are not conserved across species. Species: Pangolin (Manis javanica), dog (Canis lupus familiaris), cattle (Bos taurus), and human (Homo sapiens) 
Table 1 Presence and absence of NLR genes in pangolins and other mammals

\begin{tabular}{|c|c|c|c|c|c|c|c|}
\hline Gene & Ligand, function ${ }^{1}$ & Main expression site (adult) & Human & Cattle & Dog & Pangolin & Gene evolution \\
\hline NOD1 & Ligand: DAP (peptidoglycan) & Lung and most other organs & + & + & + & + & Conserved \\
\hline NOD2 & Ligand: MDP (peptidoglycan) & Bone marrow, skin & + & + & + & - & Loss in pangolins \\
\hline NLRC3 & Ligand: DNA; inhibition & Lymph node, spleen & + & + & + & + & Conserved \\
\hline NLRC4 & Ligand: flagellin & Appendix, bone marrow & + & + & - & - & Loss in pangolins and Caniformia \\
\hline NLRC5 & MHC class I gene expression & Spleen, lymph node & + & + & + & + & Conserved \\
\hline NLRP1 & Proteolysis, dsRNA & Skin, spleen, lymph node & + & + & + & + & Conserved \\
\hline NLRP2 & Early embronic development & Placenta, testis, bladder & + & + & + & - & Loss in pangolins \\
\hline NLRP3 & Stimulus: Potassium efflux & Bone marrow & + & + & + & + & Conserved \\
\hline NLRP4 & Early embronic development & Testis & + & - & - & - & Origin in Euarchontoglires \\
\hline NLRP5 & Early embronic development & Testis & + & + & + & - & Loss in pangolins \\
\hline NLRP6 & Antimicrobial defense & Intestine, duodenum & + & + & + & + & Conserved \\
\hline NLRP7 & Early embronic development & Testis & + & + & - & - & Loss in pangolins and dog \\
\hline NLRP8 & Early embronic development & Testis, prostate & + & + & + & - & Loss in pangolins \\
\hline NLRP9 & Ligand: dsRNA & Prostate, testis & + & + & + & - & Loss in pangolins \\
\hline NLRP10 & Anti-inflammatory & Skin & + & - & + & - & Loss in pangolins \\
\hline NLRP11 & Anti-inflammatory & Testis & + & - & - & - & Origin in primates \\
\hline NLRP12 & Anti-inflammatory & Bone marrow & + & + & + & + & Conserved \\
\hline NLRP13 & Unknown & Testis & + & + & + & - & Loss in pangolins \\
\hline NLRP14 & Early embronic development & Testis & + & + & + & - & Loss in pangolins \\
\hline NLRX1 & Anti-inflammatory & Esophagus, skin & + & + & + & + & Conserved \\
\hline CIITA & MHC class II gene expression & Bone marrow & + & + & + & + & Conserved \\
\hline \multirow[t]{3}{*}{ NAIP } & Ligand: flagellin & Appendix, spleen & + & + & - & - & Loss in pangolins and Caniformia \\
\hline & & Number of NLRs: & 20 & 15 & 15 & 8 & \\
\hline & & Number of NLRPs: & 14 & 11 & 11 & 4 & \\
\hline
\end{tabular}

$D A P \gamma$-D-glutamyl-meso-diaminopimelic acid, $M D P$ muramyl dipeptide, $d s$ double-stranded

${ }^{1}$ Ligands and functions of several NLRPs are uncertain. Only subsets of proposed functions are listed

\section{Discussion}

The results of this study show that pangolins lack numerous NLRs, suggesting that the evolution of pangolins was compatible with or even supported by the loss of these pattern recognition receptors and the associated defense processes. This study was focused on pangolins because (1) previous investigations had suggested a partial degeneration of antiviral and antimicrobial defense in these peculiar mammals (Kotze et al. 2016; Fischer et al. 2020a, b; Sharma et al. 2020) and (2) a better understanding of pathogen-host interactions in pangolins might help to evaluate the potential role of pangolins in the origin of zoonoses such as Covid-19 (Lam et al. 2020; Xiao et al. 2020; Zhang et al. 2020; Niu et al. 2021). Our findings lend support to the notion that the innate immune system of pangolins is unique among mammals and provide a basis for further investigations into the possible role of pangolins as reservoirs of pathogens that might benefit from the lack of NLR-dependent defense mechanisms.

NOD2 is inactivated by multiple mutations in pangolins, whereas it is conserved in all other mammalian species inves- tigated (Suppl. Fig. S1) and human NOD2 loss-of-function mutations cause Crohn's disease, a chronic inflammatory intestinal disease (Nayar et al. 2021). In non-mammalian vertebrates, NOD2 is evolutionarily conserved in fish (Nayar et al. 2021) but not in reptiles (Choo et al. 2019). NOD2 is primarily required for antibacterial defense but has also been implicated in antiviral defense and general sensing of perturbations of cellular homeostasis, in particular the formation of sphingosine-1-phosphate (Pei et al. 2021). Recently, a drug that targets NOD2 was shown to have antiviral activity against SARS-CoV-2 and other RNA viruses (Limonta et al. 2021). It is conceivable that NOD2-dependent responses to specific intracellular bacteria or viruses are not required or even detrimental for pangolins, possibly due to unfavorable reactions against commensal microorganisms. Furthermore, NOD2-independent defense mechanisms may have evolved in pangolins. Studies on tissues or cells of pangolins are required to test these hypotheses.

Both cytosolic sensors of bacterial flagellin, i.e., NLRC4 and NAIP, have been lost in pangolins, making them in this regard similar to species of the clade Caniformia (doglike carnivorans) (Eckhart et al. 2009) and pigs (Dawson 
et al. 2017; Sakuma et al. 2017). Strikingly, the endosomal receptor of flagellin, TLR5, has also been lost in pangolins (Sharma et al. 2020), suggesting that the response of pangolins to flagellated bacteria is uniquely degenerated. It is conceivable that these gene losses are linked to the evolution of a special gut microbiome due to the solely insectivorous diet or to the evolution of tolerance to specific pathogen groups in pangolins. Thus, it remains to be elucidated whether the response to flagellated bacteria, such as Salmonella typhimurium, Legionella pneumophila, and Shigella flexneri, with pathogenic potential in other species is suppressed in pangolins.

The number of NLRP genes varies among mammalian species (Tian et al. 2009). Until recently, the limited availability and quality of genome sequences has hampered a comprehensive study of NLRP genes across mammals. Our data show that pangolins have fewer NLRPs than dog, cattle, and humans. NLRP4, NLRP11, and possibly also NLRP7 have originated after the divergence of the phylogenetic lineages leading to humans and pangolins, but the presence of NLRP2, NLRP10, and NLRP14 in a common ancestor of humans and pangolins can be inferred from their distribution in other mammals (Table 1). Therefore, at least NLRP2, NLRP10, and NLRP14 have been lost in pangolins. NLRP10 is expressed predominantly in the skin where it is transcriptionally upregulated during epidermal cornification (Lachner et al. 2017). Keratinocyte cell death by cornification, like apoptosis and unlike pyroptosis, does not induce pro-inflammatory signaling, and we have put forward the hypothesis that NLRP10 contributes to the suppression of inflammation during cornification (Eckhart and Tschachler 2018). NLRP10 may have been lost in the course of the evolutionary adaptation of the integument in pangolins, which is characterized by an almost complete replacement of hairy skin by keratinous scales.

Remarkably, all nine reproduction-associated NLRPs of humans, i.e., NLRP2, NLRP4, NLRP5, NLRP7, NLRP8, NLRP9, NLRP11, NLRP13, and NLRP14 (Tian et al. 2009), lack orthologs in pangolins. The loss of NLRPs that are associated with germ cell biology and embryonic development (Table 1) suggests that the reproduction of pangolins does not depend on NLRP-mediated processes, which are not understood at present but may include the control of inflammation (Amoushahi et al. 2019; Yin et al. 2020; Carriere et al. 2021). Deepening the knowledge on the physiology of reproduction and embryology of pangolins would be beneficial for conservation aspects of these highly endangered species as breeding efforts in zoos are scarce (Yang et al. 2007; Sipos and Lutonsky 2021).

In summary, the repertoire of NLRs is greatly reduced in pangolins as compared to other mammals, which indicates diversification of immune defense and reproduction-related processes during the evolution of different mammalian lineages. Pangolins, presumably anergic to a series of otherwise pathogenic agents, may carry distinct microbes and viruses that can be transmitted to other species and potentially give rise to as-yet-unknown zoonoses. Therefore, comparative studies of innate immunity in pangolins and other mammals are warranted.

Supplementary information The online version contains supplementary material available at https://doi.org/10.1007/s00251-021-01230-9.

Author contribution M. S. and L. E. designed the study. M. S. and L. E. performed bioinformatic analyses. M. S. and L. E. wrote the first draft of the manuscript. All authors commented on and edited previous versions of the manuscript. All authors read and approved the final manuscript.

Funding The research was supported in part by the Austria Science Fund (FWF): P32777. Open access funding provided by Medical University of Vienna.

Availability of data and material All data and material of this study are publicly available.

Code availability Not applicable.

\section{Declarations}

Ethics approval Not applicable. No procedures requiring ethics approval were performed in this study.

Consent to participate Not applicable.

Consent for publication Not applicable.

Conflict of interest The authors declare no competing interests.

Open Access This article is licensed under a Creative Commons Attribution 4.0 International License, which permits use, sharing, adaptation, distribution and reproduction in any medium or format, as long as you give appropriate credit to the original author(s) and the source, provide a link to the Creative Commons licence, and indicate if changes were made. The images or other third party material in this article are included in the article's Creative Commons licence, unless indicated otherwise in a credit line to the material. If material is not included in the article's Creative Commons licence and your intended use is not permitted by statutory regulation or exceeds the permitted use, you will need to obtain permission directly from the copyright holder. To view a copy of this licence, visit http://creativecommons.org/licenses/by/4.0/.

\section{References}

Abe T, Lee A, Sitharam R, Kesner J, Rabadan R, Shapira SD (2017) Germ-cell-specific inflammasome component NLRP14 negatively regulates cytosolic nucleic acid sensing to promote fertilization. Immunity 46:621-634. https://doi.org/10.1016/j.immuni.2017. 03.020

Altschul SF, Gish W, Miller W, Myers EW, Lipman DJ (1990) Basic local alignment search tool. J Mol Biol 215:403-410. https://doi. org/10.1016/S0022-2836(05)80360-2 
Andersen KG, Rambaut A, Lipkin WI, Holmes EC, Garry RF (2020) The proximal origin of SARS-CoV-2. Nat Med 26:450-452. https://doi.org/10.1038/s41591-020-0820-9

Amoushahi M, Sunde L, Lykke-Hartmann K (2019) The pivotal roles of the NOD-like receptors with a PYD domain, NLRPs, in oocytes and early embryo development. Biol Reprod 101:284-296. https:// doi.org/10.1093/biolre/ioz098

Carriere J, Dorfleutner A, Stehlik C (2021) NLRP7: from inflammasome regulation to human disease. Immunology 163:363-376. https://doi.org/10.1111/imm.13372

Chakraborty J, Ghosh P (2020) Advancement of research on plant NLRs evolution, biochemical activity, structural association, and engineering. Planta 252:101. https://doi.org/10.1007/ s00425-020-03512-0

Chen ST, Chen L, Lin DS, Chen SY, Tsao YP, Guo H, Li FJ, Tseng WT, Tam JW, Chao CW, Brickey WJ, Dzhagalov I, Song MJ, Kang HR, Jung JU, Ting JP (2019) NLRP12 regulates anti-viral RIG-I activation via interaction with TRIM25. Cell Host Microbe 25:602-616.e7. https://doi.org/10.1016/j.chom.2019.02.013

Choo SW, Rayko M, Tan TK, Hari R, Komissarov A, Wee WY, Yurchenko AA, Kliver S, Tamazian G, Antunes A, Wilson RK, Warren WC, Koepfli KP, Minx P, Krasheninnikova K, Chen J, Shang S, Wu X, Zhong H, Zhao C, Wei Q, Zhang H, Xia T, Chen Y, Zhang H, Tang X (2019) Genomic analysis and adaptive evolution of the RIG-I-like and NOD-like receptors in reptiles. Int J Biol Macromol 134:1045-1051. https://doi.org/10.1101/gr.203521.115

Choo SW, Rayko M, Tan TK, Hari R, Komissarov A, Wee WY, Yurchenko AA, Kliver S, Tamazian G, Antunes A, Wilson RK, Warren WC, Koepfli KP, Minx P, Krasheninnikova K, Kotze A, Dalton DL, Vermaak E, Paterson IC, Dobrynin P, Sitam FT, Rovie-Ryan JJ, Johnson WE, Yusoff AM, Luo SJ, Karuppannan KV, Fang G, Zheng D, Gerstein MB, Lipovich L, O’Brien SJ, Wong GJ (2016) Pangolin genomes and the evolution of mammalian scales and immunity. Genome Res 26:1312-1322. https:// doi.org/10.1101/gr.203521.115

Danilova N (2006) The evolution of immune mechanisms. J Exp Zool B Mol Dev Evol 306:496-520. https://doi.org/10.1002/jez.b. 21102

Danis J, Mellett M (2021) Nod-like receptors in host defence and disease at the epidermal barrier. Int J Mol Sci 22:4677. https://doi. org/10.3390/ijms22094677

Dawson HD, Smith AD, Chen C, Urban JF Jr (2017) An in-depth comparison of the porcine, murine and human inflammasomes; lessons from the porcine genome and transcriptome. Vet Microbiol 202:2-15. https://doi.org/10.1016/j.vetmic.2016.05.013

Eckhart L, Ballaun C, Uthman A, Gawlas S, Buchberger M, Fischer $\mathrm{H}$, Tschachler E (2009) Duplication of the caspase-12 prodomain and inactivation of NLRC4/IPAF in the dog. Biochem Biophys Res Commun 384:226-223. https://doi.org/10.1016/j.bbrc.2009. 04.092

Eckhart L, Ballaun C, Uthman A, Kittel C, Stichenwirth M, Buchberger M, Fischer H, Sipos W, Tschachler E (2005) Identification and characterization of a novel mammalian caspase with proapoptotic activity. J Biol Chem 280:35077-35080. https://doi.org/10.1074/ jbc.C500282200

Eckhart L, Tschachler E (2018) Control of cell death-associated danger signals during cornification prevents autoinflammation of the skin. Exp Dermatol 27:884-891. https://doi.org/10.1111/exd.13700

Elinav E, Strowig T, Henao-Mejia J, Flavell RA (2011) Regulation of the antimicrobial response by NLR proteins. Immunity $34: 665-$ 679. https://doi.org/10.1016/j.immuni.2011.05.007

Fischer H, Tschachler E, Eckhart L (2020a) Cytosolic DNA sensing through cGAS and STING is inactivated by gene mutations in pangolins. Apoptosis 25:474-480. https://doi.org/10.1007/ s10495-020-01614-4
Fischer H, Tschachler E, Eckhart L (2020b) Pangolins lack IFIH1/ MDA5, a cytoplasmic RNA sensor that initiates innate immune defense upon coronavirus infection. Front Immunol 11:939. https://doi.org/10.3389/fimmu.2020.00939

Fritz JH, Ferrero RL, Philpott DJ, Girardin SE (2006) Nod-like proteins in immunity, inflammation and disease. Nat Immunol 7:1250 1257. https://doi.org/10.1038/ni1412

Geddes K, Magalhães JG, Girardin SE (2009) Unleashing the therapeutic potential of NOD-like receptors. Nat Rev Drug Discov 8:465-479. https://doi.org/10.1038/nrd2783

Heim VJ, Stafford CA, Nachbur U (2019) NOD signaling and cell death. Front Cell Dev Biol 7:208. https://doi.org/10.3389/fcell. 2019.00208

Hedges SB, Marin J, Suleski M, Paymer M, Kumar S (2015) Tree of life reveals clock-like speciation and diversification. Mol Biol Evol 32:835-845. https://doi.org/10.1093/molbev/msv037

Inohara C, McDonald C, Nuñez G (2005) NOD-LRR proteins: role in host-microbial interactions and inflammatory disease. Annu Rev Biochem 74:355-383. https://doi.org/10.1146/annurev.biochem. 74.082803 .133347

Kienes I, Weidl T, Mirza N, Chamaillard M, Kufer TA (2021) Role of NLRs in the regulation of type I interferon signaling, host defense and tolerance to inflammation. Int J Mol Sci 22:1301. https://doi. org/10.3390/ijms22031301

Kotze A, Dalton DL, Vermaak E, Paterson IC, Dobrynin P, Sitam FT, Rovie-Ryan JJ, Johnson WE, Yusoff AM, Luo SJ, Karuppannan KV, Fang G, Zheng D, Gerstein MB, Lipovich L, O'Brien SJ, Wong GJ (2016) Pangolin genomes and the evolution of mammalian scales and immunity. Genome Res 26:1312-1322. https:// doi.org/10.1101/gr.203521.115

Kuchmiy AA, D’Hont J, Hochepied T, Lamkanfi M (2016) NLRP2 controls age-associated maternal fertility. J Exp Med 213:28512860. https://doi.org/10.1084/jem.20160900

Kuss-Duerkop SK, Keestra-Gounder AM (2020) NOD1 and NOD2 activation by diverse stimuli: a possible role for sensing pathogen-induced endoplasmic reticulum stress. Infect Immun 88:e00898-e919. https://doi.org/10.1128/IAI.00898-19

Liu G, Gack MU (2020) Distinct and orchestrated functions of RNA sensors in innate immunity. Immunity 53:26-42. https://doi.org/ 10.1016/j.immuni.2020.03.017

Li X, Deng M, Petrucelli AS, Zhu C, Mo J, Zhang L, Tam JW, Ariel P, Zhao B, Zhang S, Ke H, Li P, Dokholyan NV, Duncan JA, Ting JP (2019) Viral DNA binding to NLRC3, an inhibitory nucleic acid sensor, unleashes STING, a cyclic dinucleotide receptor that activates type I interferon. Immunity 50:591-599.e6. https://doi. org/10.1016/j.immuni.2019.02.009

Li HM, Liu P, Zhang XJ, Li LM, Jiang HY, Yan H, Hou FH, Chen JP (2020) Combined proteomics and transcriptomics reveal the genetic basis underlying the differentiation of skin appendages and immunity in pangolin. Sci Rep 10:14566. https://doi.org/10. 1038/s41598-020-71513-w

Lachner J, Mlitz V, Tschachler E, Eckhart L (2017) Epidermal cornification is preceded by the expression of a keratinocyte-specific set of pyroptosis-related genes. Sci Rep 7:17446. https://doi.org/10. 1038/s41598-017-17782-4

Lam TT, Jia N, Zhang YW, Shum MH, Jiang JF, Zhu HC, Tong YG, Shi YX, Ni XB, Liao YS, Li WJ, Jiang BG, Wei W, Yuan TT, Zheng K, Cui XM, Li J, Pei GQ, Qiang X, Cheung WY, Li LF, Sun FF, Qin S, Huang JC, Leung GM, Holmes EC, Hu YL, Guan Y, Cao WC (2020) Identifying SARS-CoV-2 related coronaviruses in Malayan pangolins. Nature 583:282-285. https://doi.org/ 10.1038/s41586-020-2169-0

Limonta D, Dyna-Dagman L, Branton W, Mancinelli V, Makio T, Wozniak RW, Power C, Hobman TC (2021) Nodosome inhibition as a novel broad-spectrum antiviral strategy against arboviruses, 
enteroviruses and SARS-CoV-2. Antimicrob Agents Chemother. 65:e049121. https://doi.org/10.1128/AAC.00491-21

Nayar S, Morrison JK, Giri M, Gettler K, Chuang LS, Walker LA, Ko HM, Kenigsberg E, Kugathasan S, Merad M, Chu J, Cho JH (2021) A myeloid-stromal niche and gp130 rescue in NOD2driven Crohn's disease. Nature 593:275-281. https://doi.org/10. 1038/s41586-021-03484-5

Niu S, Wang J, Bai B, Wu L, Zheng A, Chen Q, Du P, Han P, Zhang Y, Jia Y, Qiao C, Qi J, Tian WX, Wang HW, Wang Q, Gao GF (2021) Molecular basis of cross-species ACE2 interactions with SARSCoV-2-like viruses of pangolin origin. EMBO J 40:e107786. https://doi.org/10.15252/embj.2021107786

Pei G, Zyla J, He L, Moura-Alves P, Steinle H, Saikali P, Lozza L, Nieuwenhuizen N, Weiner J, Mollenkopf HJ, Ellwanger K, Arnold C, Duan M, Dagil Y, Pashenkov M, Boneca IG, Kufer TA, Dorhoi A, Kaufmann SH (2021) Cellular stress promotes NOD1/2-dependent inflammation via the endogenous metabolite sphingosine-1-phosphate. EMBO J 40:e106272. https://doi.org/ 10.15252/embj.2020106272

Philpott DJ, Sorbara MT, Robertson SJ, Croitoru K, Girardin SE (2014) NOD proteins: regulators of inflammation in health and disease. Nat Rev Immunol 14:9-23. https://doi.org/10.1038/nri3565

Sabbah A, Chang TH, Harnack R, Frohlich V, Tominaga K, Dube PH, Xiang Y, Bose S (2009) Activation of innate immune antiviral responses by Nod2. Nat Immunol 10:1073-1080. https://doi.org/ $10.1038 /$ ni. 1782

Sakuma C, Toki D, Shinkai H, Takenouchi T, Sato M, Kitani H, Uenishi H (2017) Pig lacks functional NLRC4 and NAIP genes. Immunogenetics 69:125-130. https://doi.org/10.1007/ s00251-016-0955-5

Sipos W, Lutonsky C (2021) Amendments suggested for zoo medical research strategies with focus on the D-A-CH region. Tierarztl Prax Ausg G Grosstiere Nutztiere 49:256-260. https://doi.org/ 10.1055/a-1516-3404

Sharma V, Walther F, Hecker N, Stuckas H, Hiller M (2020) Convergent losses of TLR5 suggest altered extracellular flagellin detection in four mammalian lineages. Mol Biol Evol 37:1847-1854. https://doi.org/10.1093/molbev/msaa058

Tian X, Pascal G, Monget P (2009) Evolution and functional divergence of NLRP genes in mammalian reproductive systems. BMC Evol Biol 9:202. https://doi.org/10.1186/1471-2148-9-202

Ting JP, Willingham SB, Bergstralh DT (2008) NLRs at the intersection of cell death and immunity. Nat Rev Immunol 8:372-379. https://doi.org/10.1038/nri2296

Tong ZB, Gold L, Pfeifer KE, Dorward H, Lee E, Bondy CA, Dean J, Nelson LM (2000) Mater, a maternal effect gene required for early embryonic development in mice. Nat Genet 26:267-268. https:// doi.org/10.1038/81547
Wang P, Zhu S, Yang L, Cui S, Pan W, Jackson R, Zheng Y, Rongvaux A, Sun Q, Yang G, Gao S, Lin R, You F, Flavell R, Fikrig E (2015) Nlrp6 regulates intestinal antiviral innate immunity. Science 350:826-830. https://doi.org/10.1126/science.aab3145

Williams KL, Lich JD, Duncan JA, Reed W, Rallabhandi P, Moore C, Kurtz S, Coffield VM, Accavitti-Loper MA, Su L, Vogel SN, Braunstein M, Ting JP (2005) The Caterpiller protein monarch-1 is an antagonist of toll-like receptor-, tumor necrosis factor alpha-, and Mycobacterium tuberculosis-induced pro-inflammatory signals. J Biol Chem 280:39914-39924. https://doi.org/10.1074/jbc. M502820200

Wolf AJ, Underhill DM (2018) Peptidoglycan recognition by the innate immune system. Nat Rev Immunol 18:243-254. https://doi.org/ 10.1038/nri.2017.136

Xiao K, Zhai J, Feng Y, Zhou N, Zhang X, Zou JJ, Li N, Guo Y, Li X, Shen X, Zhang Z, Shu F, Huang W, Li Y, Zhang Z, Chen RA, Wu YJ, Peng SM, Huang M, Xie WJ, Cai QH, Hou FH, Chen W, Xiao L, Shen Y (2020) Isolation of SARS-CoV-2-related coronavirus from Malayan pangolins. Nature 583:286-289. https://doi.org/10. 1038/s41586-020-2313-x

Yang CW, Chen S, Chang CY, Lin MF, Block E, Lorentsen R, Chin JS, Dierenfeld ES (2007) History and dietary husbandry of pangolins in captivity. Zoo Biol 26:223-230. https://doi.org/10.1002/zoo. 20134

Yin Y, Cao S, Fu H, Fan X, Xiong J, Huang Q, Liu Y, Xie K, Meng TG, Liu Y, Tang D, Yang T, Dong B, Qi S, Nie L, Zhang H, Hu H, Xu W, Li F, Dai L, Sun QY, Li Z (2020) A noncanonical role of NOD-like receptor NLRP14 in PGCLC differentiation and spermatogenesis. Proc Natl Acad Sci U S A 117:22237-22248. https://doi.org/10.1073/pnas.2005533117

Zhang P, Dixon M, Zucchelli M, Hambiliki F, Levkov L, Hovatta O, Kere J (2008) Expression analysis of the NLRP gene family suggests a role in human preimplantation development. PLoS One 3:e2755. https://doi.org/10.1371/journal.pone.0002755

Zhang T, Wu Q, Zhang Z (2020) Probable pangolin origin of SARSCoV-2 associated with the COVID-19 outbreak. Curr Biol 30:1346-1351. https://doi.org/10.1016/j.cub.2020.03.022

Zhang Q, Zmasek CM, Godzik A (2010) Domain architecture evolution of pattern-recognition receptors. Immunogenetics 62:263-272. https://doi.org/10.1007/s00251-010-0428-1

Zhong Y, Kinio A, Saleh M (2013) Functions of NOD-like receptors in human diseases. Front Immunol 4:333. https://doi.org/10.3389/ fimmu.2013.00333

Publisher's Note Springer Nature remains neutral with regard to jurisdictional claims in published maps and institutional affiliations. 